\title{
PENINGKATAN KEMAMPUAN BERPIDATO SISWA KELAS VI SEKOLAH DASAR NEGERI ARCA KECAMATAN SUKAMAKMUR KABUPATEN BOGOR MELALUI TEKNIK STAND UP COMEDY
}

\author{
Asep Sukron ${ }^{1}$, Bambang Yulianto ${ }^{2}$, Setya Yuwana ${ }^{3}$ \\ ${ }^{1}$ Mahasiswa Program Pascasarjana, Prodi Pendidikan Dasar, Universitas Negeri Surabaya, \\ ${ }^{2 \& 3}$ Dosen Pascasarjana, Prodi Pendidikan Dasar, Universitas Negeri Surabaya \\ e-mail: archamanic@gmail.com
}

\section{Received : November 2018}

Reviewed : Desember 2018

Accepted : Januari 2019

Published : Januari 2019

\section{ABSTRACT}

The purpose of this research was to improve the ability of public speaking's student by using stand up comedy technique of grade sixth SDN Arca subdistrict Sukamakmur, Bogor. The subject consisted of 30 students, 12 males, 18 females. The problems in this research is the low ability of speaking's student in therms linguistic factors or nonlingusitic factors. Besides that, the learning are not interesting, boring and the result of the learning have not reached minimum completenes criteria established by school. This study was classroom action research (CAR) it was conducted with two cycles, each cycle consisted of planning, conducting, observation, and reflection of Kemmis and Taggart Model. Related with the quality of student's learning result by using stand up comedy technique, it showed that student's abilities were improved. These abilities were regularity the delivery of ideas, sentence and word accuracy, fluency and naturalness, articulation and intonation, courage and trust, the precision of set up and punch line technique, the precision of one liner technique, and the precision of act out technique. The Results of research on learning cycle one, indicating that speech abilities of students through the techniques of stand up comedy has increased by $67 \%$ and the end of the second cycle of $90 \%$. Based on data analysis, found an increased percentage of students in speech amounted to $23 \%$. It can be concluded that learning through stand up comedy techniques to improve the ability of speech sixth grade students of SDN Arca Sukamakmur District of Bogor regency on the initial hypothesis can be accepted and proven.

Key Words: Stand Up Comedy Technique, Speaking Ability of Student.

\section{ABSTRAK}

Penelitian ini bertujuan untuk meningkatkan kemampuan berpidato melalui teknik stand up comedy pada siswa kelas VI SDN Arca Kecamatan Sukamakmur Kabupaten Bogor dengan subjek 30 siswa, terdiri atas 12 siswa laki-laki dan 18 siswi perempuan. Permasalahan dalam penelitian ini adalah rendahnya kemampuan berbicara siswa dalam hal faktor-faktor kebahasaan maupun nonkebahasaan. Di samping itu, pembelajaran kurang menarik, membosankan, dan hasil pembelajaran belum mencapai Kriteria Ketuntasan Minimal (KKM) yang ditetapkan oleh Sekolah. Penelitian ini adalah Penelitian Tindakan Kelas (PTK) yang dilaksanakan dalam 2 siklus, setiap siklus terdiri atas perencanaan, pelaksanaan, observasi dan refleksi model Kemmis dan Taggart. Berkenaan dengan kualitas kemampuan berpidato anak dengan teknik stand up comedy menunjukkan bahwa kemampuan siswa dapat meningkat. Kemampuan tersebut adalah keruntutan penyampaian gagasan, ketepatan kalimat dan kata, kelancaran dan kewajaran, artikulasi dan intonasi, keberanian dan percaya, ketepatan set up dan punch line, ketepatan teknik one liner, dan ketepatan teknik act out. Hasil penelitian pada pembelajaran siklus I, menunjukkan bahwa kemampuan berpidato siswa melalui teknik stand up comedy mengalami peningkatan sebesar $67 \%$ dan akhir siklus II 
sebesar $90 \%$. Berdasarkan analisis data tersebut, ditemukan persentase peningkatan siswa dalam berpidato sebesar 23\%. Sehingga dapat disimpulkan bahwa pembelajaran melalui teknik stand up comedy untuk meningkatkan kemampuan berpidato siswa kelas VI SDN Arca Kecamatan Sukamakmur Kabupaten Bogor pada hipotesis awal dapat diterima dan terbukti.

Kata kunci: Teknik Stand Up Comedy, Kemampuan Berpidato Siswa.

\section{PENDAHULUAN}

Kemampuan berbicara siswa kelas VI SD Negeri Arca masih rendah. Hal itu terlihat pada kegiatan pembelajaran bahasa Indonesia dengan materi menceritakan kembali cerita yang disampaikan oleh guru. Data yang diperoleh pada observasi awal dari tiga puluh Siswa di kelas VI, sebanyak 18 siswa atau $60 \%$ mengalami kesulitan ketika berbicara dengan kata lain belum mencapai nilai kriteria ketuntasan minimal (KKM) yang telah ditetapkan yaitu 62. Sementara itu, sekitar 12 orang atau $40 \%$ siswa telah mencapai ketuntasan minimal atau tuntas. Pembelajaran dikatakan tuntas jika kelas tersebut terdapat minimal $85 \%$ siswa telah mencapai KKM.

Data tersebut merupakan data yang digunakan untuk melakukan refleksi dalam pelaksanaan pembelajaran yang telah dilakukan. Selain itu, hasil ulangan akhir semester, aktivitas siswa saat pelaksanaan pembelajaran berlangsung juga menjadi dasar untuk melakukan refleksi. Sikap siswa ketika berbicara terlihat malu-malu dan asal-asalan dalam penampilannya.

Selain hal-hal di atas, siswa kurang mampu berbicara menggunakan bahasa Indonesia dan mengalami kesulitan ketika pembelajaran berbicara di depan kelas. Hal itu disebabkan pada saat pembelajaran siswa kurang percaya diri apabila secara formal diminta untuk berbicara di depan kelas. Di samping itu, siswa hanya mengenal bahasa daerah, sehingga dialek bahasa daerah sangat memengaruhi pelafalan kata. Apalagi SD Negeri Arca merupakan Sekolah yang berbatasan dengan kabupaten lain. Dari hal tersebut, peneliti sebagai guru kelas segera introspeksi dan refleksi. Apa yang kurang atau yang salah dari pembelajaran yang baru saja dilaksanakan.

Ada banyak alternatif untuk meningkatkan kemampuan berbicara siswa, antara lain melalui wawancara, cerita berpasangan, pidato tanpa teks, pidato dengan teks, mengomentari film/ sinetron/ cerpen/ novel, debat, membawakan acara, memimpin rapat, menerangkan obat/makanan/minuman atau benda lainnya, bermain peran, info berantai, dan cerita berangkai (Sugandi, 2004:112121). Teori belajar bahasa yang mendukung dan relevan dengan teori ini adalah teori Behavioris, Nativisme, dan teori Fungsional.
Alternatif terpilih untuk meningkatkan kemampuan berbicara dalam hal ini berpidato yaitu teknik stand up comedy. Sementara itu, pengertian stand up comedy itu sendiri adalah bentuk dari seni komedi atau melawak yang disampaikan secara monolog kepada penonton. Berangkat dari pengertian tersebut, pembelajaran bahasa di kelas bisa dilaksanakan secara menarik dan menyenangkan siswa dengan teknik tersebut. Pembelajaran bahasa dengan menggunakan teknik stand up comedy salah satu usaha mengubah cara pandang siswa dalam belajar bahasa. Berkenaan dengan cara pandang belajar bahasa, Yulianto (2009:58) mengemukakan bahwa bahasa Indonesia sebagai disiplin ilmu pengetahuan, selama ini, cenderung dipandang ilmu yang monoton ataupun membosankan. Karena itu, banyak anak didik yang malas untuk belajar bahasa Indonesia.

Adapun yang menjadi fokus utama pembelajaran dengan teknik stand up comedy adalah pada ketercapaian kompetensi dasar bahasa Indonesia di semester II. Selain itu, perlu diperhatikan tingkat proporsionalitas dalam pembelajaran di kelas, jangan sampai muatan komedi lebih mendominasi dibandingkan dengan materi pembelajaran yang harus didapatkan oleh siswa. Tentu, akan lebih bijaksana apabila guru memilih dan mencoba menggunakan metode strategi, dan teknik yang kreatif, inovatif serta menyenangkan dalam proses pembelajaran.

Memerhatikan latar belakang di muka, maka rumusan masalah penelitian ini adalah apakah teknik stand up comedy dapat meningkatkan kemampuan berpidato siswa kelas VI SDN Arca Kecamatan Sukamakmur Kabupaten Bogor. Untuk mempermudah pelaksanaan penelitian, rumusan umum tersebut diperinci menjadi masalah khusus yaitu bagaimana peningkatan kualitas perencanaan, pelaksanaan, aktivitas siswa, respon siswa dan peningkatan kemampuan berbicara siswa sesudah diterapkannya teknik stand up comedy.

Adapun tujuan umum sesuai dengan rumusan masalah di atas, yakni mendeskripsikan peningkatan kemampuan berpidato dalam pembelajaran bahasa Indonesia melalui teknik stand up comedy di Kelas VI SDN Arca Kecamatan Sukamakmur Kabupaten Bogor. 


\section{KAJIAN PUSTAKA}

Dilihat dari segi kebebasan peserta didik memilih bahasa untuk mengungkapkan gagasan, berpidato mempunyai mempunyai persamaaan dengan tugas bercerita. Dalam kehidupan bermasyarakat, aktivitas berbicara melalui pidato banyak dikenal dan dilakukan orang, misalnya pidato sambutan, upacara bendera, dan termasuk dimaksudkan disini ceramah-ceramah. Untuk melatih kemampuan siswa mengungkapkan gagasan dalam bahasa yang tepat dan cermat, tugas berpidato baik untuk diajarkan dan diujikan di Sekolah. Ujian berbahasa lisan dengan tugas berpidato pun tinggi kadar keotentikannya.

Tarigan (1997:73) menyampaikan pidato atau berpidato adalah berbicara di hadapan orang banyak (di depan umum) dalam rangka menyampaikan suatu masalah untuk mencapai suatu tujuan tertentu, misalnya untuk bermusyawarah, memberikan rujukan dan sebagainya. Berpidato juga merupakan suatu kegiatan menyampaikan gagasan secara lisan dengan menggunakan penalaran yang tepat serta memanfaatkan aspek-aspek nonkebahasaan (ekspresi wajah, kontak pandang, gerak tangan dan lainlain) yang dapat mendukung efisiensi dan efektifitas pengungkapan gagasan kepada orang banyak dalam suatu acara tertentu.

Metode pembelajaran dijabarkan ke dalam teknik dan gaya pembelajaran. Teknik pembelajaran dapat diartikan sebagai cara yang dilakukan seseorang dalam mengimplementasikan suatu metode secara spesifik. Sementara menurut Gerlach dan Ely (dalam Hamzah B Uno, 2009: 2) teknik adalah jalan, alat, atau media yang digunakan oleh guru untuk mengarahkan kegiatan peserta didik ke tujuan yang ingin dicapai. Dalam kamus besar bahasa Indonesia, teknik diartikan sebagai metode atau sistem mengerjakan sesuatu, cara membuat atau melakukan sesuatu yang berhubungan dengan seni.

Berkenaan dengan pengertian stand up comedy, Papana (2012:4) mengemukakan bahwa stand up comedy merupakan bentuk dari seni komedi atau melawak yang disampaikan secara monolog kepada penonton. Biasanya ini dilakukan secara live dan komedian akan melakukan one man show. Meskipun disebut dengan stand up comedy, komedian tidaklah selalu berdiri dalam menyampaikan komedinya. Ada beberapa komedian yang melakukannya dengan duduk dikursi persis seperti orang yang sedang bercerita.

Sejalan dengan pengertian tersebut, peneliti mengemukakan bahwa stand up comedy dalam pembelajaran adalah kegiatan pembelajaran dengan menggunakan teknik-teknik stand up comedy untuk mencapai kompetensi suatu materi pelajaran. Teknik ini bisa kita gunakan di kelas oleh guru, dengan cara menyisipkan materi pelajaran ke dalam materi lawakan ataupun sebaliknya.

Joke atau lawakan dalam stand up comedy memiliki struktur dasar yang memang sangat mendasar. Secara tradisional joke terdiri dari 2 bagian yaitu set-up dan punch (punch Line), set-up adalah bagian pertama dari joke yang mempersiapkan tertawa dan punch adalah bagian kedua yang membuat kita tertawa (Papana, 2012:83).

\section{METODE PENELITIAN}

Berbagai macam pendekatan penelitian yang dilakukan guru dalam memperbaiki kualitas pembelajaran di kelas, salah satunya adalah penelitian tindakan kelas. Penelitian ini merupakan penelitian tindakan kelas yang merupakan jenis penelitian kuantitatif yang berlatar belakang permasalahan pembelajaran di kelas untuk mendapatkan solusi ilmiah dalam mengatasi permasalahan kegiatan belajar mengajar. Penelitian tindakan kelas ini bertujuan memperbaiki proses pembelajaran yang dimulai dari rancangan pembelajaran, proses, hingga hasil belajar. Selanjutnya, guru kelas berkolaborasi dalam perencanaan, pelaksanaan tindakan, dan evaluasi hasil.

Setelah melakukan evaluasi guru melakukan refleksi diri dan upaya pemecahannya dengan melakukan berbagai tindakan yang terencana dalam situasi nyata serta menganalisis setiap pengaruh dari tindakan tersebut. Refleksi diri dilakukan karena guru mengalami masalah dalam proses pembelajaran. Rancangan penelitian ini menggunakan rancangan PTK. Prosedur PTK menggambarkan adanya tahapan siklus sebagai berikut.

Tahap I menyusun rancangan tindakan atau perencanaan. Perencanaan dalam setiap siklus disusun untuk perbaikan pembelajaran. Ada dua jenis perencanaan yang disusun, yakni perencanaan awal dan perencanaan lanjutan. Perencanaan awal diturunkan dari berbagai asumsi perbaikan hasil dari kajian studi pendahuluan, sedangkan perencanaan lanjutan disusun berdasarkan hasil refleksi setelah mempelajari berbagai kelemahan yang harus diperbaiki.

Tahap II pelaksanaan tindakan dan pengamatan. Pelaksanaan tindakan yaitu implementasi atau penerapan rancangan pembelajaran yang sudah direncanakan dan perlakuan yang dilaksanakan oleh guru sesuai dengan fokus masalah. Pada saat pelaksanaan tindakan sambil dilakukan pengamatan atau observasi. Observasi dilakukan untuk mengumpulkan informasi tentang proses pembelajaran yang dilakukan guru sesuai dengan rencana tindakan yang telah disusun. Hasil observasi dapat 
dijadikan masukan ketika guru melakukan refleksi untuk penyusunan rencana ulang dalam siklus berikutnya.

Tahap III Refleksi. Kegiatan untuk mengemukakan kembali apa yang sudah dilakukan. Dalam refleksi ini guru bertanya pada diri sendiri dan dibantu teman sejawat apakah kekurangan dan kelebihan pelaksanaan pembelajaran yang sudah dilakukan.

Subjek penelitian ini adalah Guru sekaligus sebagai peneliti dan siswa kelas VI dengan jumlah 30 siswa yang terdiri atas 12 siswa laki-laki dan 18 siswi perempuan.

\section{HASIL PENELITIAN}

Perencanaan pembelajaran siklus I didasarkan data awal pengamatan yang dilakukan oleh peneliti dibantu wali kelas, pada 11 Desember 2015. Berdasarkan pengamatan, diketahui bahwa siswa kelas VI SD Negeri Arca Kecamatan Sukamakmur Kabupaten Bogor memiliki kemampuan berbicara yang masih rendah, baik dari aspek kebahasaan maupun nonkebahasaan. Hal tersebut dilihat dari hasil kemampuan siswa dalam bercerita tidak memenuhi target atau dengan kata lain sekitar 60\% siswa belum mencapai Kriteria Ketuntasan Minimal (KKM) yang ditetapkan Sekolah dan hanya $40 \%$ siswa yang tuntas. Di samping itu, skor tertinggi hanya didapatkan oleh satu orang dengan perolehan 77 dan skor terendah dengan perolehan 46 .

Berdasarkan pengamatan awal tersebut, peneliti mengadakan perbaikan dengan membuat perencanaan pembelajaran. Hasil yang diperoleh dari kegiatan perencanaan tersebut yaitu Rencana Pelaksanaan Pembelajaran (RPP), LKS, kisi-kisi soal, rubrik penilaian dan pedoman penskoran, analisis materi pembelajaran, dan lembar pengamatan.

Selanjutnya, perangkat pembelajaran pada siklus I divalidasi oleh dua validator dengan menggunakan lembar validasi yang berisikan tentang komponen-komponen perangkat RPP pada Permendiknas tahun 2006.

\section{Perkembangan Kemampuan Berpidato Melalui Teknik Stand up Comedy Siklus I}

Berikut ini dipaparkan data kemampuan berbicara dalam hal ini berpidato hasil pembelajaran melalui teknik stand up comedy pada siklus I. Data ini merupakan hasil analisis yang dilakukan peneliti ketika selesai melaksanakan pembelajaran di Kelas VI SD Negeri Arca Kecamatan Sukamakmur Kabupaten Bogor.

Hasil pembelajaran siklus I, diketahui ada 10 siswa tidak memenuhi target atau dengan kata lain sekitar 33\% siswa belum mencapai Kriteria Ketuntasan Minimal
(KKM) yang ditetapkan Sekolah, terdiri dari 4 laki-laki dan 6 siswa perempuan. Sementara itu, hanya $67 \%$ siswa yang tuntas, terdiri atas 8 siswa laki-laki dan 12 siswi perempuan.

Secara rinci kemampuan berpidato siswa melalui teknik stand up comedy pada aspek penilaian keruntutan penyampaian gagasan memperoleh akumulasi jumlah 96 dengan nilai rata-rata 3,3 sehingga dapat dikatakan unsur penilaian ini dengan kategori "sangat baik". Pada aspek ketepatan kalimat dan kata, kelancaran dan kewajaran, artikulasi dan intonasi memperoleh kategori "baik". Akumulasi jumlah penilaian dan rata-rata masing-masing penilaian tersebut adalah 95, 88, dan 89 , sedangkan ratarata 3,2 untuk ketepatan kalimat dan kata, 2,93 untuk kelancaran dan kewajaran, serta 2,94 untuk artikulasi dan intonasi.

\section{Siklus II}

Berikut ini data kemampuan berpidato siswa melalui teknik stand up comedy hasil pembelajaran siswa kelas VI SDN Arca pada siklus II diketahui bahwa tes diikuti oleh 30 siswa, dan siswa yang mencapai ketuntasan sebanyak 27 siswa, sedangkan yang belum mencapai nilai maksimal dalam penampilannya atau dengan kata lain belum mencapai ketuntasan sebanyak 3 siswa.

Untuk mengetahui peningkatan nilai dari siklus I dan Siklus II, berikut disajikan data gabungan kemampuan berpidato dengan teknik stand up comedy hasil pembelajaran siklus I dan siklus II.

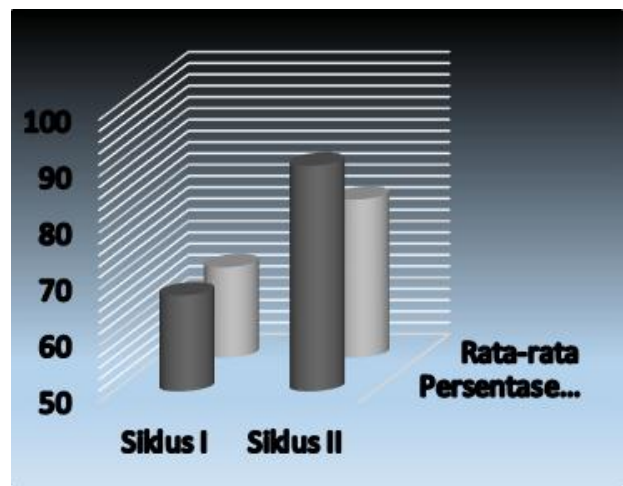

Gambar 1.

Peningkatan Ketuntasan Hasil Belajar

Berdasarkan gambar di atas, kita dapat melihat peningkatan kemampuan berpidato siswa siklus I dan II yang diperoleh dari hasil pembelajaran. Dari grafik warna abu-abu menunjukkan persentase ketuntasan siswa dari siklus I ke II sebesar 67\% menjadi 90\%, sedangkan grafik berwarna putih menunjukkan peningkatan rata-rata nilai siswa dari 66 menjadi 78 . 


\section{PEMBAHASAN}

Pelaksanaan pembelajaran bahasa Indonesia ketika melakukan pengambilan data awal dapat dikatakan kurang baik, sehingga belum mampu meningkatkan kemampuan berbicara siswa. Hal tersebut dapat dilihat dari hasil kemampuan belajar siswa berdasarkan analisis data hasil pembelajaran pada bagian sebelumnya.

Pada saat pembelajaran masih banyak siswa yang tidak terlibat dalam pembahasan, anggota kelompok ada yang asyik sendiri, ada yang bermain-main, dan ada pula yang diam saja. Tampaknya, hal ini terjadi karena banyak alasan. Penyebab yang pertama mungkin berasal dari guru. Hasil refleksi menunjukkan bahwa guru tidak menegur anggota kelompok yang bermain-main dan tidak mengingatkan siswa akan tugasnya. Guru hanya berkelilling ke kelompok-kelompok tanpa bertanya atau memberi teguran. Ini menunjukkan bahwa guru belum peka terhadap penyimpangan yang terjadi di Kelas (Julaeha, 2003).

Kemudian penyebab selanjutnya adalah kurangnya metode dan teknik yang inovatif dalam pembelajaran bahasa, sehingga pembelajaran kurang menarik dan membosankan. Penyampaian materi pelajaran masih didominasi metode ceramah oleh guru. Akhirnya, banyak siswa yang hanya mendengarkan penjelasan guru dan keterlibatan siswa dalam berbicara kurang maksimal. Hal tersebut menyebabkan pembelajaran kurang menarik. Disamping itu, penyebab juga berasal dari siswa, pada saat pembelajaran siswa kurang berani dan percaya diri apabila secara formal diminta untuk berbicara di depan kelas.

Hal ini senada dengan pendapat Slameto (1995:35) bahwa kegiatan belajar dipengaruhi oleh beberapa faktor, diantaranya adalah media pembelajaran dan model pembelajaran, pemilihan media yang tepat dapat membantu siswa untuk membentuk pengertian di dalam jiwanya sehingga siswa dapat mengaplikasikannya dalam kehidupan sehari-hari.

Berbeda dengan pelaksanaan pembelajaran berpidato yang dilakukan melalui teknik stand up comedy, siswa sangat antusias dan tertarik dengan pembelajaran yang dilakukan guru. Sebagian besar dari mereka merasa heran dan kagum ketika guru menayangkan video anak yang di bawah usianya, sudah mampu berpidato dengan gaya stand up comedy. Tayangan video tersebut memotivasi siswa untuk melakukan hal yang sama.

Berkenaan dengan hal-hal di atas, Sadiman (2009:18) mengemukakan bahwa media dapat menyalurkan pesan dan dapat merangsang pikiran, perasaan, perhatian, dan kemauan siswa sehingga dapat mendorong terjadinya proses belajar pada diri siswa.
Setelah guru menjelaskan maksud penggunaan media tersebut, akhirnya semua siswa fokus dan menaruh perhatian penuh terhadap pembelajaran.

Pada saat penampilan perwakilan kelompok untuk berpidato dengan teknik stand up comedy, awalnya mereka masih malu-malu dan tidak berani untuk tampil dihadapan teman-temannya. Setelah dukungan dari rekan-rekan kelompoknya berupa yel-yel kelompok dapat meningkatkan semangat, akhirnya tidak malu-malu, berani dan percaya diri untuk tampil di depan kelas. Ditambah lagi, dengan penjelasan guru bahwa penampilan anggota kelompok memengaruhi terhadap penilaian kelompok.

Selanjutnya, penilaian kemampuan berpidato melalui teknik stand up comedy, jumlah siswa yang mencapai hasil ketuntasan minimal berangsur-angsur naik, sehingga pada siklus kesatu, jumlah tersebut berkembang dibandingkan dengan pembelajaran sebelumnya, meskipun pada siklus kesatu ini masih jauh dibawah target, akan tetapi mengalami perkembangan. Hal ini terjadi karena guru selalu memperhatikan masukan dan pertanyaan dari siswa dan pengamat, sehingga selalu berusaha memperbaiki pembelajaran dan mencoba mengembangkan metode, teknik dan media agar tujuan pembelajaran tercapai. Hal ini sesuai dengan prinsip-prinsip keterampilan dasar mengajar, khususnya keterampilan bertanya (Wardani, 2003). Sebagaimana yang terungkap dari data yang dikumpulkan oleh pengamat, perhatian guru tidak hanya terpusat kepada anak-anak yang tampil di depan kelas, tetapi ke seluruh siswa.

Selain perkembangan pembelajaran siklus pertama, pembelajaran siklus kedua pada kegiatan awal seluruh langkah pembelajaran terlaksana sangat baik. Penetapan kontrak dengan siswa dan penyesuaian alokasi waktu yang tidak terlaksana pada siklus pertama, pada siklus kedua dapat terlaksana. Hal ini karena guru mempersiapkan rencana pelaksanaan pembelajaran dan media yang diperlukan sudah dipersiapkan jauh-jauh hari. Ini menunjukkan bahwa guru memiliki kompetensi pedagogik yang cukup baik. Kegiatan merancang dan memahami potensi peserta didik sebagai salah satu kemampuan yang harus dimiliki guru. Kemampuan merancang dan melaksanakan pembelajaran serta memahami karakteristik peserta didik merupakan salah satu kompetensi pedagogik guru (Suharsimi, 2006).

Jumlah siswa laki-laki meskipun kaum minoritas di Kelas, tetapi menjadi teamwork bagi siswa perempuan dalam kelompok. Kejadian menarik lagi ketika siswa masing-masing kelompok untuk melakukan penampilan di depan kelas, bila melakukan kesalahan dalam berpidato, membuat seluruh kelas bersorak dan ramai menertawai 
siswa lain. Kesalahan tersebut sesuai yang dikemukakan Raskin (1985:100) Kesalahan ketika berbicara merupakan bentuk komunikasi humor, karena pembicara berhumor dengan tidak disengaja, pembicara berhumor dengan sengaja, pendengar tidak mengharapkan humor, dan pendengar mengharapkan humor.

\section{Perkembangan Kemampuan Berpidato Siswa Melalui Teknik Stand up Comedy}

Tujuan dari pelaksanaan penelitian ini adalah untuk meningkatkan kemampuan berbicara siswa dalam pembelajaran bahasa Indonesia, dengan demikian segala hal yang terdapat dalam penelitian ini merupakan keseluruhan upaya untuk mewujudkan tujuan tersebut. Adapun hal yang difokuskan untuk terwujudnya tujuan dari penelitian ini yaitu penggunaan teknik stand up comedy dalam kegiatan pembelajaran agar kemampuan berpidato siswa lebih berkembang.

Setelah menggunakan teknik stand up comedy dalam melaksanakan pembelajaran berpidato kepada siswa yang dilakukan pada perbaikan siklus pertama dan kedua, ternyata banyak perubahan positif yang bisa diraih dalam pembelajaran. Teknik ini mampu meningkatkan kemampuan berpidato siswa. Pengalaman belajar yang diharapkan adalah terjadinya aktivitas yang tinggi dari siswa. Pendekatan yang digunakan untuk membentuk pengalaman siswa adalah pendekatan keterampilan proses. Keterampilan proses merupakan pendekatan belajarmengajar yang mengarah pada pengembangan kemampuan-kemampuan mental, fisik dan sosial yang mendasar sebagai penggerak kemampuan-kemampuan yang lebih tinggi dalam diri siswa (Depdikbud dalam Udin S. Winataputra, dkk, 1990)

Berdasarkan hasil penelitian yang telah dianalisis, kemampuan berpidato siswa sesudah diterapkannya teknik stand up comedy, berangsur-angsur mengalami perkembangan. Kegiatan pembelajaran bahasa Indonesia melalui teknik stand up comedy, memberikan dampak positif terhadap hasil belajar siswa pada aspek-aspek kebahasaan dan nonkebahasaan. Keberanian dan rasa percaya diri siswa timbul dengan diterapkannya teknik ini.

Ketika identifikasi awal sebelum penelitian, jumlah siswa yang berani dan percaya diri untuk tampil berbicara pada materi bercerita sangat sulit. Kondisi seperti inilah yang digunakan peneliti bersama guru kelas selaku teman sejawat untuk mengadakan refleksi. Disamping itu, refleksi juga dilakukan dengan siswa agar terjadi proses yang sinergi antara guru dan siswa. Melalui refleksi siswa mengendapkan apa yang baru dipelajarinya sebagai struktur pengetahuan yang baru dalam pengayaan atau revisi dari pengetahuan sebelumnya (Suyanto, 2002:11)

Jumlah siswa berpenampilan ke arah teknik stand up comedy pada pembelajaran siklus pertama hanya beberapa orang saja. Penyebab utamanya adalah siswa baru pertama kali bahwa ada teknik tersebut, sehingga peneliti perlu menampilkan variasi pembelajaran dengan teknik ini pada pembelajaran selanjutnya sebagai bahan refleksi. Langkah ini sebagai model kreatif dalam variasi pembelajaran yang harus dikembangkan guru.

Sehubungan dengan hal di atas, Ambarawa (2008:43) mengemukakan bahwa dalam model-model pembelajaran kreatif mengadakan variasi merupakan keterampilan yang harus dikuasai guru dalam pembelajaran. Tujuannya untuk mengatasi kebosanan peserta didik agar mereka selalu antusias, tekun, dan selalu berpartisipasi.

Berbeda dengan perkembangan kemampuan berpidato siswa pada pembelajaran siklus kedua, mengalami perkembangan yang signifikan. Hasil evaluasi pembelajaran berupa tes mandiri kemampuan berpidato dengan teknik stand up comedy ditemukan jumlah siswa yang mengalami perkembangan pada aspek keruntutan penyampaian gagasan secara runtut dan jelas sebanyak 17 siswa. Selain itu, sekitar 12 siswa berpidato secara runtut saja. Hal ini disebabkan pada perbaikan siklus kedua, peneliti mengembangkan pembelajaran dengan mengatasi permasalahan yang masih kurang pada siklus pertama. Kegiatan guru yang tidak terlaksana, dapat terlaksana pada perbaikan kedua ini.

Berdasarkan uraian di atas, terlihat bahwa hipotesis awal dapat diterima bahwa pembelajaran melalui teknik stand up comedy untuk meningkatkan kemampuan berpidato siswa kelas VI SDN Arca Kecamatan Sukamakmur Kabupaten Bogor terbukti. Dengan demikian pembelajaran dikatakan berhasil atau tuntas, sehingga peneliti merasa cukup melaksanakan sampai dengan siklus II.

\section{Kelebihan dan Kekurangan Teknik Stand up Comedy dalam Pembelajaran}

Teknik stand up comedy dalam pembelajaran bahasa Indonesia untuk meningkatkan kemampuan berpidato siswa kelas VI SDN Arca Kecamatan Sukamakmur Kabupaten Bogor yang dilakukan peneliti, mempunyai kelebihan dan kekurangan. Adapun kelebihan yang ditemukan peneliti dalam teknik ini yaitu (1) memotivasi dan meningkatkan ketertarikan siswa pada pembelajaran yang dilakukan guru, (2) mampu mengembangkan faktor-faktor kebahasaan dan 
nonkebahasaan siswa, (3) pembelajaran lebih menyenangkan dan tidak membosankan, dan mengembangkan kemampuan berpidato siswa.

Sedangkan kekurangan teknik stand up comedy dalam pembelajaran yang dilakukan yaitu (1) pembelajaran dengan teknik ini siswa memerlukan waktu yang cukup, (2) teknik ini lebih cocok untuk siswa laki-laki, (3) teknik ini memerlukan penguasaan materi yang lama, dan (4) teknik ini hanya dikuasai sebagian siswa saja.

\section{SIMPULAN}

Berdasarkan hasil penelitian yang telah dilakukan untuk menjawab rumusan masalah dapat ditarik kesimpulan sebagai berikut.

1. Perencanaan pelaksanaan pembelajaran yang disusun telah memenuhi standar kualifikasi sangat baik dan layak sesuai dengan kurikulum 2006.

2. Pelaksanaan pembelajaran, untuk aspek keterlaksanaan dan ketercapaian RPP Siklus I belum mencapai indikator keberhasilan dalam penelitian, sehingga siklus dilanjutkan. Akan tetapi pada siklus II Keterlaksanaan dan ketercapaian RPP sebagai aktivitas guru meningkat dan mencapai indikator keberhasilan, sehingga siklus berikutnya dirasa cukup dan dapat dihentikan.

3. Perkembangan kemampuan berpidato siswa dari siklus I ke II meningkat dari persentase ketuntasan $67 \%$ menjadi 90\%, sehingga pembelajaran dikatakan berhasil atau tuntas. Dengan demikian, hipotesis awal dapat diterima dan terbukti. Oleh karena itu, peneliti merasa cukup melaksanakan sampai dengan siklus kedua.

\section{SARAN}

Berdasarkan hasil penelitian yang telah dilakukan oleh peneliti dalam meningkatkan kemampuan berpidato siswa kelas VI SDN Arca Kecamatan Sukamakmur Kabupaten Bogor, saran yang diberikan oleh peneliti sebagai berikut.

1. Sebelum pelaksanaan pembelajaran melalui teknik stand up comedy dalam meningkatkan kemampuan berpidato siswa kelas VI SDN Arca, hendaknya guru mempersiapkan perangkat pembelajarannya dengan seksama dan teliti;

2. Guru diharapkan menggunakan metode dan teknik serta media maupun alat peraga sebagai sarana menyampaikan materi pelajaran agar pembelajaran lebih menarik, antusias dan menyenangkan siswa serta tidak membosankan; dan
3. Penelitian tentang pembelajaran dengan teknik stand up comedy ini, perlu dikembangkan lebih lanjut untuk menjawab secara tuntas perkembangan kemampuan berpidato siswa, baik faktor-faktor kebahasaan maupun nonkebahasaan.

\section{DAFTAR PUSTAKA}

Amalia, Riska Nur. (2014). Keefektifan Media Tayang Stand up Comedy Dalam Pembelajaran Mengonversi Teks Anekdot.Universitas Pendidikan Indonesia. Tidak Dipublikasikan.

Arikunto, Suharsimi. (2006). Penelitian Tindakan Kelas. Jakarta: Bumi Aksara.

Indarti, Titik. (2008). Penelitian Tindakan Kelas (PTK) dan Penulisan llmiah. Surabaya: Lembaga Penerbit FBS Unesa.

Burhan. (2012). Penilaian Pembelajaran Bahasa Berbasis Kompetensi. Yogyakarta. BPFE Yogyakarta.

Sadiman, Arief S. Et. All. (2010). Media Pendidikaan: Pengertian, Pengembangan, dan Pemanfaatannya. Jakarta: Rajawali Pers.

Suhartono. (2005). Pengembangan Keterampilan Berbicara Anak Usia Dini. Jakarta. Depdiknas. (153 tesis)

Suryanti, Sukartiningsih, dkk. (2008). Model-Model Pembelajaran Inovatif. Surabaya: Unesa University Press.

Tarigan, Henri Guntur. (2008). Berbicara sebagai Sesuatu Keterampilan Berbahasa. Bandung : angkasa Bandung

Trianto, (2013). Mendesain Model Pembelaajaran Inovatif-Progresif Konsep, Lnadasan, dan Implementasi pada KTSP. Jakarta. Kencana

Uno, Hamzah B. (2008). Perencaanaan Pembelajaran. Jakarta. Bumi Aksara

Yulianto, Bambang. (2009). Model Pembelajaran Inovatif Bahasa Indonesia. Surabaya: Unesa University Press.

Yulianto, Bambang. (2011). Pengantar Teori Belajar Bahasa. Surabaya: Unesa University Press. 